\title{
O Estado Novo, a cunhagem da palavra 'portugalidade' e as tentativas da sua reabilitação na atualidade
}

\author{
Vitor Sousa \\ Centro de Estudos de Comunicação e Sociedade, Universidade do Minho \\ E-mail: vitorsousadics.uminho.pt
}

\begin{abstract}
Resumo
A cunhagem da palavra 'portugalidade' ocorreu entre as décadas de 50 e 60 do século XX, sendo um produto do Estado Novo. Trata-se de um processo que foi sublinhado após a revogação, em 1951, do Ato Colonial, em que as colónias passaram a denominar-se províncias ultramarinas e em que foi disseminado o slogan "Portugal do Minho a Timor" destinado a combater os movimentos independentistas que lá emergiam, defendendo a pertença desses territórios a Portugal. Foi em 1947, com a publicação do opúsculo Em Defesa da Portugalidade,

da autoria de Alfredo Pimenta que, pela primeira vez, alguém se debruçou de forma específica sobre a 'portugalidade', discorrendo sobre o seu significado e tipificando o conceito. Após um hiato na sua utilização, na sequência da revolução do 25 de abril, em que se verificou um distanciamento em relação a assuntos que eram característicos do Estado Novo, o termo vai sendo reintroduzido no léxico, não fugindo no entanto ao ideário luso-tropicalista em que foi forjado (Ferronha, 1969), provocando vários equívocos.
\end{abstract}

Palavras-chave: Alfredo Pimenta; Estado Novo; 'portugalidade'; luso-tropicalismo; identidade nacional.

\begin{abstract}
The coining of the word 'Portugality' ['portugalidade'] is identified as having taken place between the 50 and 60 decades of the twentieth century, being a 'Estado Novo' (dictatorship period, between 19281974) product. That dynamic was underlined after the repeal, in 1951, of the 'Colonial Act', where the colonies would be called as overseas provinces and the slogan "Portugal form Minho to Timor" was dis-

seminated, to combat the independence movements that emerged, defending that territories belonged to Portugal. It was in 1947, with the publication of the booklet In Defense of Portugality [Portugalidade], wroten by Alfredo Pimenta, that for the first time, someone studied specifically the 'portugality' ['portugalidade], discussing its meaning and typifying the concept. After a hiatus in its use, following the 'Car-
\end{abstract}

Data de submissão: 2017-11-13. Data de aprovação: 2017-12-04.

A Revista Estudos em Comunicação é financiada por Fundos FEDER através do Programa Operacional Factores de Competitividade - COMPETE e por Fundos Nacionais através da FCT - Fundação para a Ciência e a Tecnologia no âmbito do projeto Comunicação, Filosofia e Humanidades (LabCom.IFP) UID/CCI/00661/2013.

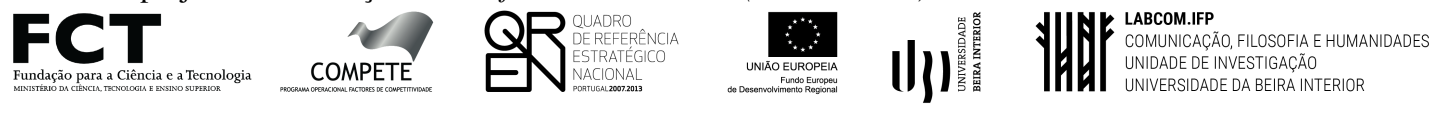


nation Revolution' (April, 1974), in which there was a distance from certain subjects that were characteristic of the Estado Novo, the term is being reintroduced into the lexicon, but it does not escape to the Luso-Tropicalist ideology in which it was forged (Ferronha, 1969), causing several misunderstandings.

\section{Keywords: Alfredo Pimenta; 'Estado Novo'; 'Portugality' ['portugalidade']; Luso-Tropicalism; national identity.}

\section{Nota Introdutória}

A cunhagem da palavra 'portugalidade' é apontada pelo portal Ciberdúvidas da Língua Portuguesa como tendo ocorrido entre as décadas de 50 e 60 do século XX, o que faz com que seja um produto do Estado Novo. O conceito perseguia a ideia de que as ex-colónias fossem vistas pela ONU não como territórios autónomos, mas como parte integrante de Portugal. Tratou-se de um processo que avançou de forma acentuada após a revogação, em 1951, do Ato Colonial de 1930, em que as colónias passaram a denominar-se províncias ultramarinas. A nossa investigação corroborou essa perspetiva através da análise de conteúdo dos discursos dos deputados da Assembleia Nacional (AN) que, a partir dessa altura, mais exatamente desde 27 de abril de 1951, utilizam pela primeira vez a palavra 'portugalidade' nas intervenções parlamentares sublinhando, assim, no discurso político, a 'portugalidade' como sinónimo de Portugal e as suas colónias como um todo uno e indivisível, traduzido pela frase "Portugal do Minho a Timor".

Mas, um pouco antes do que preconiza o Ciberdúvidas, em 1947, a publicação do opúsculo Em Defesa da Portugalidade, da autoria de Alfredo Pimenta, já incluía a palavra. Esta foi, de resto, a primeira vez que um autor se debruçou de forma específica sobre a 'portugalidade', discorrendo sobre o seu significado e tipificando o conceito. Ideologicamente alinhado com Salazar e defensor da 'tradição', Pimenta evidencia um discurso que o próprio denomina de antiparlamentar, antipartidário e anticomunista, autointitulando-se como doutrinador de 'portugalidade'.

$\mathrm{Na}$ sequência da revolução do 25 de abril, em resultado do corte ideológico com o regime deposto, e após um hiato na utilização do conceito 'portugalidade' ele vai sendo reintroduzido no dia-a-dia dos portugueses, seja pela classe política (através de alguns discursos, a maioria dos quais com um recorte luso-tropicalista), dos profissionais de marketing ou de branding (que o utilizam em publicidades e estudos de mercado em que o foco assenta na ideia 'made in Portugal', ou apelando a eventuais 'particularidades' portuguesas), ou pela via de situações aleatórias, provocando vários equívocos.

\section{Enquadramento Metodológico}

A metodologia utilizada nesta investigação assenta na hermenêutica, fundamentalmente na interpretação de textos, desconstruindo eventuais níveis de significação que se venham a encontrar (Derrida, 1982 [1971]). A tarefa de ler e interpretar textos aproxima o trabalho ao do filósofo e do crítico literário, contrariando, de certo modo, a via quase exclusiva da utilização de ferramentasfétiche por parte da maior parte dos cientistas sociais, como assinala Moisés de Lemos Martins 
(2011). Ou, como refere Paul Ricoeur (2013 [1987]), a hermenêutica constitui uma teoria da interpretação dos discursos, assumindo-se como dialética entre 'explicação' e 'compreensão'. O que significa que 'explicar' é a tentativa de descrever a referência, e em que as hipóteses, leis e teorias são submetidas à verificação prática da realidade; enquanto 'compreender' se afirma como o significado das mensagens.

O olhar metodológico não é, no entanto, estanque cruzando algumas possibilidades existentes, como no caso de Michel Foucault (2010 [1975]), para quem uma teoria só é útil se possibilitar condições para que os objetivos sejam atingidos, como acontece com uma caixa de ferramentas. Deste modo, recorreu-se à referida caixa de ferramentas, por exemplo, para proceder a alguma análise de conteúdo, nomeadamente quando se analisaram as bases de dados do parlamento português relativamente à utilização da palavra 'portugalidade': durante a Assembleia Nacional (AN), entre 12-1-1935 e 20-4-1974 (11 legislaturas) e durante 12 legislaturas da Assembleia da República (de 3-6-1976 a 14-9-2012). Achamos importante perceber a lógica dos debates parlamentares, uma vez que num sistema político representativo, como é o português, os deputados desempenham funções em nome da sociedade. Como refere Abdoolkarim Vakil, "por muito que às vezes o esqueçamos, os debates parlamentares acompanham (..) refletem e enformam os discursos académicos e os debates no espaço público" (Vakil, 2006: 85).

Para concretizar a análise relativa ao uso da palavra 'portugalidade' nos discursos dos deputados portugueses, foi utilizada a base de dados do Parlamento português que está disponível na Internet ${ }^{1}$. Para o efeito, através da palavra-chave 'portugalidade' foram, primeiro, visualizados o conjunto dos dados existentes na referida base de dados, quer durante o período da Assembleia Nacional (AN), entre 1935 e 1974, quer após a Revolução do 25 de abril, em plena Assembleia da República (AR), entre 1976 e $2012^{2}$, no sentido de se poder ficar com uma visão de conjunto. Depois, foram analisados todos os diários resultantes da busca efetuada, observando o contexto em que a palavra 'portugalidade' tinha sido utilizada, criando categorias para os dois períodos referidos e agrupando por temas os resultados obtidos.

Em relação às fontes consultadas, foram utilizadas publicações, necessariamente datadas, uma vez que a 'portugalidade' também ela está datada, sendo que a propaganda do regime do Estado Novo incentivou a edição de várias obras relativas a esta temática. Foram os casos do opúsculo de Alfredo Pimenta, "Em defesa da portugalidade" (1947) e do livro de António Ferronha, "Ideário de Portugalidade. Consciência da Luso/Tropicalidade" (1969). Paralelamente, foram utilizadas várias publicações atuais, nomeadamente dos próprios média, na tentativa de observar a forma de como os protagonistas políticos, nomeadamente o ex-Presidente da República, Cavaco Silva e o atual Chefe de Estado, Marcelo Rebelo de Sousa, utilizavam/utilizam a palavra 'portugalidade', para além de outros protagonistas, como ministros e deputados (como foram os casos da exministra da Cultura, Gabriela Canavilhas e do ex-deputado Manuel Alegre).

1. Disponível em http://debates.parlamento.pt. Acesso em 21/5/2011.

2. A análise desenvolvida no período correspondente à Assembleia da República vai até ao ano 2012, até ao final da primeira sessão legislativa da XII legislatura, que terminou em 14/9/2012. 


\section{A 'Portugalidade': do Pioneirismo de Alfredo Pimenta na Utilização da Palavra, ao Ideário Luso-Tropicalista do Conceito}

\section{- Em Defesa Da Portugalidade (1947), de Alfredo Pimenta}

Como já referimos, a primeira vez que encontramos escrita a palavra 'portugalidade' foi na publicação Em Defesa Da Portugalidade (1947), daí a importância que reputamos ao opúsculo de Alfredo Pimenta. Enquadrando-se na dinâmica política do Estado Novo, o autor mostra-se um apaniguado de Salazar, a quem se refere como um deus. Alfredo Pimenta (Guimarães, 1882 Lisboa, 1950) foi o responsável pela organização e direção do Arquivo Municipal de Guimarães (1931), tendo sido, também, diretor do Arquivo Nacional da Torre do Tombo (1949). Autor de uma vasta bibliografia foi, também, um dos maiores polemistas do seu tempo ${ }^{3}$. Católico e monárquico, foi simpatizante do socialismo anarquista, tendo militado no Partido Evolucionista, que abandonou em 1915, data em que adere à monarquia, já com a I Guerra Mundial em curso. Foi próximo do Integralismo Lusitano, tendo fundado a 'Acção Realista Portuguesa' (1923) entrando, mais tarde, em rotura com aquele grupo tradicionalista, mantendo-se contudo um defensor acérrimo da monarquia e da sua restauração, pela qual sempre se bateu. Foi designado, em finais de 1938, presidente do Instituto de Cultura Política, ligado à Causa Monárquica. Não obstante, na sua juventude, Alfredo Pimenta foi adepto do socialismo, "com o seu ideário de messianismo e redenção" (Cruz, 2008: 6), estando entre os defensores do socialismo societário e descentralizador.

A publicação de Em Defesa Da Portugalidade decorre do discurso que Alfredo Pimenta proferiu em Guimarães (Restaurante Jordão), em 11 de outubro de 1947, repasto de confraternização com amigos, que realizava anualmente numa localidade diferente do Minho. Imbuído de uma dinâmica autoelogiosa, Alfredo Pimenta assumia-se como "doutrinador político e social, o expositor da Monarquia e do Nacionalismo integral, do Autoritarismo contra-revolucionário, do Tradicionalismo católico e ocidental - numa palavra, o doutrinador de Portugalidade" (Pimenta, 1947: 12), e recusava, desde logo, a associação da 'portugalidade' a outros epítetos, como a lusitanidade:

Nem da Latinidade - termo que nada significa, por amplo de mais; nem da Hispanidade, que nos absorve e confunde; nem da Lusitanidade, que nos abastarda. Não somos latinos, nem somos hispanos, nem somos lusitanos, somos portugueses! A Latinidade é uma categoria histórica, sem base concreta; a Hispanidade tem Castela por centro; a Lusitanidade tem por lar a Lusitânia que não é toda nossa. Só a Portugalidade é inteiramente nossa, característica e tipicamente nossa. Portugalenses, portugaleses, portugueses, assim nos chamamos e nos chamaram, ao nascer; assim nos chamamos e nos chamaram, durante séculos, até que a pedantaria dos humanistas nos crismou de - lusitanos (Pimenta, 1947: 12-13).

Ao longo das 31 páginas do opúsculo (26 das quais de texto efetivo), Alfredo Pimenta utiliza a expressão "doutrinador de Portugalidade" por 13 vezes, justificando-a com o apelo à monarquia,

3. António José de Brito diz ser incontestável que Alfredo Pimenta foi um grande polemista "cujos mais destacados combates se travaram no plano das ideias, constituindo até por vezes lutas em defesa de uma determinada concepção do mundo" (Brito, 1982). A mesma opinião tem Manuel Braga da Cruz, que se refere a Alfredo Pimenta como "um dos mais aguerridos e temidos polemistas do seu tempo" (Cruz, 2008: 6). 
porque "foi a Monarquia que fez Portugal", destacando contudo estar a referir-se à "Monarquia pura, a Monarquia tradicional, a que vem de 1128, se afirma em Ourique, se consolida em Aljubarrota, rasga o caminho marítimo da Índia, cria o Império" e, depois, claudica, sucumbindo "devagar, em Alcácer", ressuscitando em 1640, muito embora volte a cair "apunhalada pelas costas, em 1834, em Évora-Monte" (Pimenta, 1947: 14). Uma monarquia, como acentua, assente na 'portugalidade'. É por isso que se afirma inimigo da democracia, que refere ter entrado em Portugal através "das mochilas das hordas napoleónicas representativas da Revolução Francesa", que veio "dementar" os portugueses, instalando-se no poder em 1820 e tomando conta definitiva do estado em 1834, "sob a máscara da Monarquia", através de D. Pedro, e "sem máscara", com a implantação da República em 5 de outubro de 1910, "por obra e graça da Carbonária de Lisboa" (Pimenta, 1947: 15). O liberalismo político, para o autor, também não poderia ser ligado à "portugalidade', reputando-o mesmo de seu inimigo, uma vez que matara "as liberdades profissionais ou corporativas, e as regalias municipais - preanunciando o Standardismo comunista", o mesmo se passando em relação ao parlamentarismo, que encarava como uma "falsificação do Supremo Interesse Nacional" (Pimenta, 1947: 15). Muito embora idolatrasse Salazar ${ }^{4}$, Pimenta observava que ele estava a fazer um Estado Novo com gente velha, referindo ser necessário doutrinadores, nomeadamente a partir da escola, criticando o amolecimento ideológico da União Nacional, e vislumbrando traços comunistas em todo o lado, mesmo no Governo.

Escrito no pós-II Guerra Mundial, no opúsculo Em Defesa da Portugalidade, lembram-se os 'avisos' que este autor fizera em relação à emergência da Rússia e dos perigos do alargamento do Comunismo à Europa unificada saída do conflito, salientando que o tempo lhe dera razão. Em relação a Portugal, e dirigindo-se ao povo, perguntava, de forma irónica, quem tinha razão por este se ter deixado "embalar pelo canto das sereias democráticas"? (Pimenta, 1947: 18). Ilustrava a sua posição com o facto de a Europa estar, naquela altura, faminta e destruída, resultante da "Paz que a Vitória [dos aliados] nos trouxe" (Pimenta, 1947: 19). Nesse sentido, perguntando se Salazar continuaria o mesmo, tratava de responder afirmativamente, dando, logo em seguida, "graças a Deus", pedindo que este o conservasse (Pimenta, 1947: 22). Mas questionava-se sobre se o ar, o rumo, o futuro e a tranquilidade nacional seriam os mesmos, problematizando se "o Homem [Salazar], sendo o mesmo, a sua posição seria a mesma" (Pimenta, 1947: 23). Afirmava que, pelas qualidades que Salazar tinha, apenas lhe faltava governar um estado poderoso, com o apoio militar necessário para que o povo o ouvisse e lhe obedecesse. Mais a mais, afiançava que comparar Salazar aos "Grandes reinantes" seria "ofuscá-los, sumi-los, reduzi-los à sua natural insuficiência", sustentando que só ele seria capaz "de opôr a verticalidade insuperável dos seus princípios, a inflexibilidade da sua ética, a serenidade impecável da sua austeridade, tudo o que, há perto de vinte anos, constitui o capital seguro da sua política" (Pimenta, 1947: 25). Destacava, nessa perspetiva, que Salazar falava em nome de um estado possuidor, apenas, de uma História, ao contrário do que acontecia noutros estados, que eram detentores de dinheiro e de armas para se afirmarem internacionalmente. Assim, o ditador português representava uma ideia, num "momento em que só os maquiavelismos pragmáticos valem", representava o espírito, "quando só a Matéria pesa";

4. Segundo Manuel Braga da Cruz as afinidades entre Pimenta e Salazar eram sobretudo de ordem pessoal, o que não impedia Pimenta de lhe fazer críticas violentas. Salazar tinha por ele uma elevada estima, mas nem por isso deixava de lhe sublinhar o seu desagrado para com alguns dos seus escritos (Cruz, 2008: 7-10). 
mas também, "a Lealdade, quando só a Hipocrisia se impõe"; e, finalmente, representava a mão estendida e aberta, "quando o punho cerrado se respeita e adora" (Pimenta, 1947: 26).

As referências de Pimenta a Salazar confundiam-se com as que seriam feitas em relação a uma divindade, recordando que o povo português se tinha entregue nas suas mãos há quase 20 anos, quando o país se encontrava insolvente. Dessa forma, Salazar (ou "esse homem", como a ele se refere Pimenta), "pediu confiança, e, só com ela, ergueu esse Povo, e fez desse Povo atribulado, escarnecido, desprezado, o único Povo da Europa que não precisa de esperar a esmola do pão que come", e que só não é feliz, por causa das “desgraças dos outros" (Pimenta, 1947: 26).

A 'portugalidade' de Alfredo Pimenta está ideologicamente alinhada à direita (mais precisamente, à direita da direita), não sendo, por isso, de estranhar, que faça, ainda hoje, furor nos blogues ligados à extrema-direita e assumidamente fascistas ${ }^{5}$. Católico, nacionalista e monárquico, as conceções de Pimenta podiam resumir-se no lema 'Deus, Pátria e Rei', garantindo António José de Brito que esteve quase sempre "ao serviço dessas três verdades pelas quais soube rudemente combater com a pena" e em que evidenciava que teria sido graças à transmissão hereditária desse poder que "a nação constitui como que o património de determinada família, quase se confundindo assim o bem próprio do governante com o da totalidade social a que pertence e que dirige" (Brito, 1982: 113-114). Pimenta fazia ainda questão de vincar a sua posição contrária à existência de partidos, argumentando que dividiam a nação que se pretendia una.

Trata-se de um perfil que se enquadra na lógica definida por António Costa Pinto (2015) em relação ao Estado Novo, ao sustentar que a elite fascista possuía uma origem política de direita radical: "O Estado Novo foi símbolo da hegemonia ideológica de uma direita antidemocrática de matriz tradicionalista e católica, no seu processo de formação", sendo que o catolicismo social e a Igreja "constituíram um instrumento importante de limitação à fascização do regime de Salazar" (Pinto, 2015: 338). Para o investigador, à semelhança das ditaduras de direita da mesma época, o salazarismo, "inspirou-se no largo espectro das ideologias de 'terceira via' presentes no panorama cultural deste início do século XX, sintetizando fundamentalmente elementos do catolicismo social e da direita radical maurrasiana", aproximando-se, assim "das ditaduras do mesmo período (e foram muitas...) que não conheceram algumas características que singularizaram o fascismo alemão e o fascismo italiano" (Pinto, 2015: 343). A perspetiva de António Costa Pinto é complementada por Luís Reis Torgal que, não obstante observar quem defenda que o fascismo português não é aceite como categoria politológica, o certo é que "existiu, em qualquer circunstância, como um estado organizado numa perspectiva autoritária, antidemocrática, corporativa, nacionalista, de ideologia única e repressiva" (Torgal, 2009: 366-367).

— Ideário de Portugalidade. Consciência da Luso/Tropicalidade (1969), de António Ferronha

No livro Ideário de Portugalidade. Consciência da Luso/Tropicalidade, editado em 1969, António Ferronha faz a listagem da vasta retórica e ideologia do Estado Novo sobre a temática da

5. Algumas passagens do opúsculo Em Defesa da Portugalidade podem encontrar-se nos blogues "Fascismo em Rede" [http://tinyurl.com/qghfxtu]; "Antologias em Prosa" [http://tinyurl.com/nfunfah]; e "Acção Integral" [http://tinyurl.com/okvc9kh]. 
'portugalidade' e, tal como o título anuncia, parte desse pressuposto para chegar ao conceito de 'luso-tropicalidade' através do que diz serem os seus princípios humanistas. O livro foi publicado numa altura em que estava em curso a guerra colonial (que tinha tido início, em Angola, em 1961) e com Portugal já como membro da ONU (1955). Este ideário é justificado pelo alegado desleixo dos portugueses em fixar, fosse de que forma fosse, para a posteridade, a ideia de 'portugalidade', que se seguiu às 'descobertas ultramarinas' e à criação do império colonial (que o autor apelidava "Portugalidade de Quinhentos"). Todo o discurso produzido na obra orienta a 'portugalidade' para as então províncias ultramarinas, especificamente para Angola, onde António Ferronha era formador de formadores nativos, exatamente sobre a temática da 'portugalidade', transmitindo-lhes as noções básicas desse ideário, para que estes as endossassem, depois, aos seus futuros alunos angolanos, mas reportando as suas raízes a Portugal, à 'metrópole', na tentativa de não deixar esmorecer o sentimento de alegada pertença. Ao longo do livro, o autor discorre teoricamente sobre o assunto, revelando-se este um verdadeiro manual de instruções de como transmitir a 'portugalidade', que reputa mesmo de catecismo de 'portugalidade' aplicado aos trópicos e que reflete, na globalidade, a lógica do Estado Novo sobre o assunto. O autor define por diversas vezes a palavra. Associa a 'portugalidade' ao Império, salientando que o conceito é ideológico e promove a construção da sua unidade política e cultural: "Portugal é moralmente um Império, constituído de diversíssimos territórios e etnias variadas e portador de uma ideologia que é a Portugalidade, construtora da unidade política e cultural daquele" (Ferronha, 1969: 256).

Evidencia que Portugal, "nascido à sombra protectora da Igreja" e sendo, inicialmente um corpo inicial de "visigodos, suevos, luso-romanos, moçárabes, mouros (árabes e berberes), francos, flamengos e ingleses, além dos povos de origem proto-histórica, neolítica e paleolítica" (Ferronha, 1969: 257), a que se juntaram, depois, populações africanas (sobretudo sudanesas e bantos), continuou o ideal de perenidade dos povos. Nesse sentido, o que dava unidade àquela "mixórdia de raças e de línguas, formando o corpo de Portugal era o espírito desse mesmo Portugal - a Portugalidade", que é representada "por um corpo de ideias e os sentimentos que faz com que as populações, há muito desgarradas politicamente, por vicissitudes da história militar, ainda hoje se sintam orgulhosas de sua ascendência" (Ferronha, 1969: 257). E ilustra o seu raciocínio com a imagem do que diz ser "o corpo de Portugal", constituído por 11 territórios espalhados por três continentes o que demonstra "o espírito luso-tropical naqueles que o sentem, que une esses pedaços dispersos" (Ferronha, 1969: 257).

E, numa altura em que se perspetivava o futuro das províncias ultramarinas, nomeadamente o seu desenho político-administrativo, a 'portugalidade' era invocada enquanto cimento que daria consistência à unidade de Portugal, face a uma eventual desagregação. Nesse sentido, sustentava ser suficiente do ponto de vista de política interna de Portugal, para que se pudesse pensar num federalismo futuro, enquanto organização territorial, "um governo forte, um poderoso exército um só quadro de funcionários, uma só língua unificadora, uma só história a aprender", em suma, "um só ideário de Portugalidade mentalizante, uma só moeda a circular, uma só bandeira a tremular, uma só Pátria a amar, um só povo a comprometer-se”(Ferronha, 1969: 263-264).

Para António Ferronha, a 'portugalidade' assentava num ideal de convivência luso-tropical, assumindo-se como mística, ética e política onde seria aceite a igualdade dos homens dentro do "mesmo território pátrio a fim de prosseguirem na sua jornada para o seu objectivo transcendente, 
que é, por meio da nação portuguesa, a conservação e perfeição do corpo e do espírito de cada um" (Ferronha, 1969: 266). A ideia de igualdade, plasmada numa dinâmica de distinção de raças é recorrente ao longo do livro, não obstante se advertisse, a par e passo, para os deveres daqueles que eram colonizados, observando-se que, se os cumprissem (nomeadamente falando a língua portuguesa e enquadrando-se na 'portugalidade'), não teriam problemas com os responsáveis potugueses.

\section{A 'Portugalidade' e o Discurso Político}

\section{- O Período do Estado Novo}

Como já referimos, a cunhagem da palavra 'portugalidade' é apontada pelo portal Ciberdúvidas da Língua Portuguesa como tendo tido início nas décadas de 50 e 60 do século XX (Bom, 2000), em plena vigência do Estado Novo (Duarte, 2005). Um conceito contemporâneo, portanto, do slogan "Portugal do Minho a Timor", que se desenvolveu na sequência da revogação do Ato Colonial de 1930 (Constituição de 1933), em que o Governo português defendia que Portugal seria um todo uno e indivisível, e em que todas as colónias passaram a ser designadas por províncias, tal como as outras que existiam na 'metrópole'. Foi desenvolvida a partir daí, toda uma retórica destinada a sustentar um mito que apoiasse a ideia de que não haveria razões para o desenvolvimento de movimentos independentistas nos territórios portugueses de África e da Ásia ${ }^{6}$.

Não terá sido, então, por acaso que só nessa altura (mais exatamente em 27 de abril de 1951, ou seja, 16 anos após o início da AN) que os deputados começaram a introduzir a palavra 'portugalidade' nos seus discursos, passando a AN a disseminá-la enquanto eco da governação que especificamente era. Toda essa estratégia ia no sentido de combater os movimentos independentistas que emergiam nas antigas colónias, defendendo a pertença desses territórios a Portugal, por via do seu 'destino histórico'. Esse facto seria sublinhado no discurso político da 'portugalidade', com a assunção de Portugal como um país uno e indivisível, sustentado pela ideia "Portugal do Minho a Timor'. A 'portugalidade' assentou, assim, num imaginário colonial centrado em Portugal, colocado num patamar superior relativamente às suas então colónias.

6. A palavra 'portugalidade' entrou, pela primeira vez, na dicionarização da Porto Editora em 1994, na sétima edição do "Dicionário da Língua Portuguesa". De então para cá, a palavra sofreu um ajuste que estreita a sua dimensão subjetiva, e pode ser vislumbrado pela proposta interpretativa constante do portal Infopédia (associado à Porto Editora): "Qualidade do que ou de quem é português; conjunto de traços considerados distintivos da cultura e história de Portugal; sentimento de afinidade ou de amor por Portugal" (Infopédia, 2014: S/P). Já o termo 'portugalizar' constante da quinta edição do mesmo dicionário (1965), e que foi incluído na publicação 19 anos antes da palavra 'portugalidade', começou por ser interpretado como "tornar parecido com as coisas e usos de Portugal; trazer para a civilização metropolitana os indígenas das províncias ultramarinas" (Costa \& Melo, 1965: 1130) e que, na atualidade, o portal Infopedia atualizou para "tornar(-se) parecido com a cultura, os usos e os costumes de Portugal" ou "tornar(-se) semelhante aos portugueses, sobretudo os nativos de países colonizados por Portugal” (Infopédia, 2014: S/P), o que, convenhamos, no que concerne à última ideia, se assume com um recorte algo problemático, mais a mais tendo presente que a descolonização foi feita em 1975. 
Gráfico 1. Frequência da utilização da palavra 'portugalidade' nos discursos dos deputados da Assembleia Nacional por temas (12-01-1935 a 24-04-1974)*

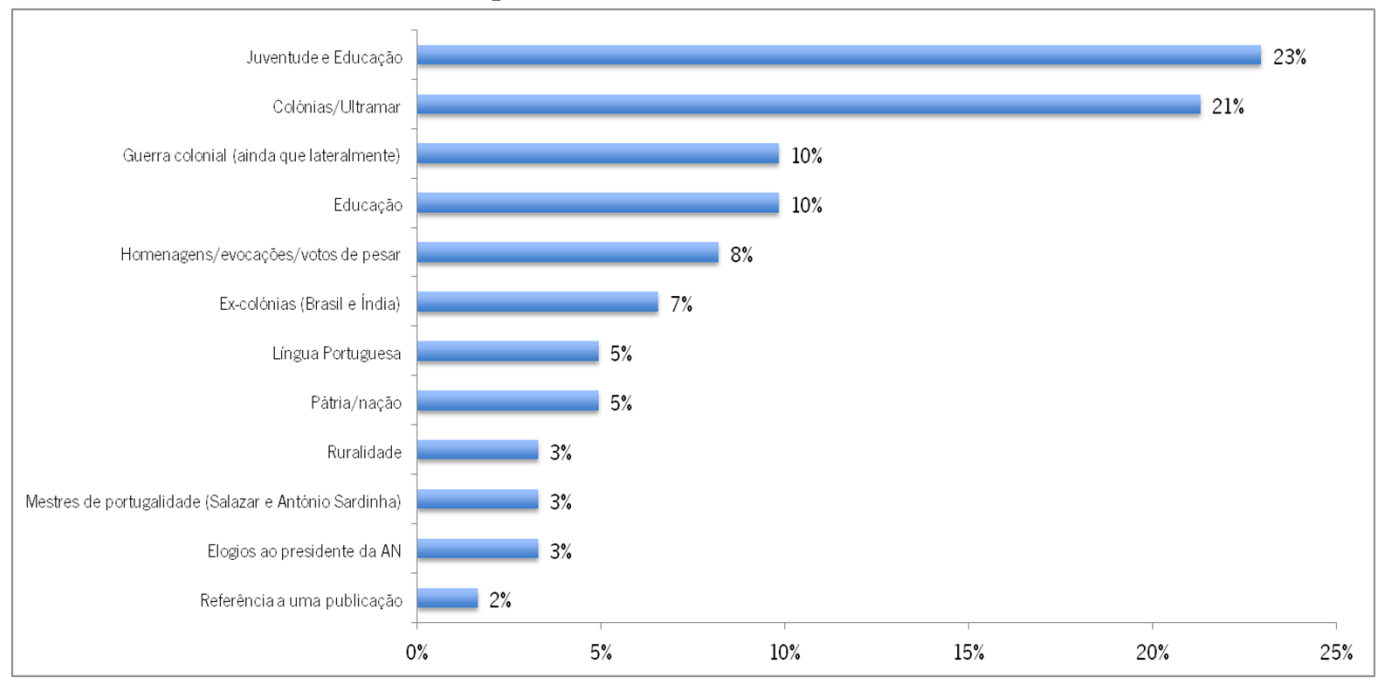

*Foram separadas, propositadamente, as categorias 'Juventude e Educação' e 'Educação', uma vez que as primeiras estão, quase sempre associadas, pelo que se optou por destacar isoladamente a 'Educação'. Sendo um dos pilares do Estado Novo, desta forma seria mais fácil observar a sua própria importância

(Sousa, 2015, p. 197).

Através da análise de conteúdo, da busca efetuada à base de dados do Parlamento utilizando a palavra-chave 'portugalidade' (desde o início da AN, em 12 de janeiro de 1935, até ao seu fim, a 24 de abril e 1974), a expressão foi encontrada por 61 vezes, em 58 páginas, referentes a 54 diários (Sousa, 2015, pp. 173-199). É sobre a educação e juventude (em conjunto) que os deputados a utilizam mais, seguindo-se a problemática das colónias/ultramar. Destacam-se, também, os assuntos ligados à guerra colonial (ainda que de uma forma dissimulada, devido à censura existente), $\mathrm{e}$ à educação; as homenagens, evocações e votos de pesar; às ex-colónias (Brasil e Índia); à língua portuguesa e à pátria/nação; à ruralidade, evocando os 'mestres' de portugalidade (no caso, Salazar e António Sardinha, considerado o 'pai' ideológico do Integralismo Lusitano) e alguns elogios ao presidente da AN; e, finalmente, a referência a uma publicação.

A palavra 'portugalidade' aparece pela primeira vez nos discursos dos deputados da AN, na sequência da apresentação de propostas conducentes à revisão da Constituição. Albino Soares Pinto dos Reis Júnior, presidente do Parlamento, anunciava o projeto de lei apresentado pelos deputados Carlos Moreira, Mário de Albuquerque, Cortês Pinto, João Ameal e Délio Nobre Santos, intitulado "Da educação, ensino e cultura nacional". Neste, era proposta a inclusão de um novo artigo, cuja redação era a seguinte: "O Estado tomará as providências necessárias tendentes à protecção e defesa da Língua, como instrumento basilar da cultura lusíada e da projecção do nome português no Mundo". Na defesa do projeto, Carlos Moreira salientava que a língua bem merecia 
a revisão do articulado, dizendo tratar-se de uma "jóia do nosso património espiritual e intelectual, veículo de portugalidade através do Mundo" 7 .

A palavra 'portugalidade' pode ser encontrada nos discursos dos deputados até ao último diário da AN publicado, datado de 24 de abril de 1974 (referente à sessão do dia anterior), dia que passaria à história como o último da AN, dado que no dia seguinte eclodiu a revolução e foi destituído o regime. Foi através de uma intervenção do deputado Roboredo e Silva que, a propósito das despesas militares e dos transportes marítimos e aéreos, fazia votos para que "os nossos irmãos de todas as raças e credos, designadamente os jovens", se debruçassem sobre o facto de os portugueses "um povo nobre e indómito que construiu uma nação imortal" e que adiantava projectar-se ainda "no meio do fermento de destruição e de morte que campeiam no mundo, na fé e na heroicidade do Portugal soldado, marinheiro e missionário que na actualidade continua a ser". E justificava a sua exaltação com "um forte sentimento de 'portugalidade"'. E, a propósito dos jovens, aproveitava para reprovar o comportamento dos "pouquíssimos que pelas suas loucuras anárquicas prejudicam a grande massa que apenas quer trabalhar e habilitar-se com a necessária ferramenta para, com confiança, enfrentar o futuro" 8 .

\section{- O Período do Pós-25 de Abril}

Após o 25 de abril de 1974 houve um distanciamento do discurso político em relação a algumas expressões e símbolos utilizados pelo Estado Novo, nomeadamente no que ao uso da palavra 'portugalidade' diz respeito (Sousa, 2015, pp. 199-214). Talvez por isso, a palavra tenha integrado o discurso dos deputados enquanto arma de arremesso político. Em 1981, por exemplo, José Manuel Mendes (PCP), criticava a maioria da Aliança Democrática (AD) que acusava de fazer sintonizar a futura lei eleitoral com outras que visavam a fabricação, "'rapidamente e em força' em doses maciças, de novos eleitores", com ou sem qualquer vínculo efetivo à pátria, na posse ou não do que apelidava de "elementos basilares em função dos quais é de consagrar a portugalidade" 9 . Dias mais tarde, o seu colega de bancada, Carlos Brito, pedia a palavra para observar que não tinha posto em causa a 'portugalidade' do deputado Mário Lopes (PSD) mas a democraticidade da posição governamental, e era sobre essa matéria que dizia existir o direito de intervir, e de acionar todos os mecanismos conducentes a um pretenso inquérito parlamentar ${ }^{10}$. Já o social-democrata Carlos Encarnação falava em atentado à 'portugalidade', criticando declarações do seu colega socialista João Cravinho à comunicação social, em que este afirmara que "canalizar mais dinheiro da CEE para Portugal dá origem a mais corrupção" 11. Silva Marques (PSD) referia que a direção do PS estava envergonhada e atordoada, numa época que apelidava de "vertiginosa de descalabro dos seus mitos e de libertação do pensamento político", sendo por isso que corria "desesperadamente atrás de ideários alheios, afivelando nervosamente uma máscara de renovação, de modernidade e de portugalidade" 12 .

7. V Legislatura, sessão 2, no 104, de 27-04-1951, incluída no diário de 28-04-1951, p. 962.

8. XI Legislatura, sessão 1, nº 54, de 23-04-1974, incluída no diário de 24-04-1974, p. 1087.

9. II Legislatura, sessão 1, no 90, de 30-06-1981, diário de 01-07-1981, p. 3723.

10. II Legislatura, sessão 1, no 92, de 08-07-1981, diário de 09-07-1981, p. 3826.

11. V Legislatura, sessão 3, no 14, de 14-11-1989, diário de 15-11-1989, p. 403.

12. V Legislatura, sessão 3, nº 68, de 26-04-1990, diário de 27-04-1990, p. 2292. 
Gráfico 2. Frequência da utilização da palavra 'portugalidade' nos discursos dos deputados da Assembleia da República por temas (03-06-1976 a 14-09-2012)*

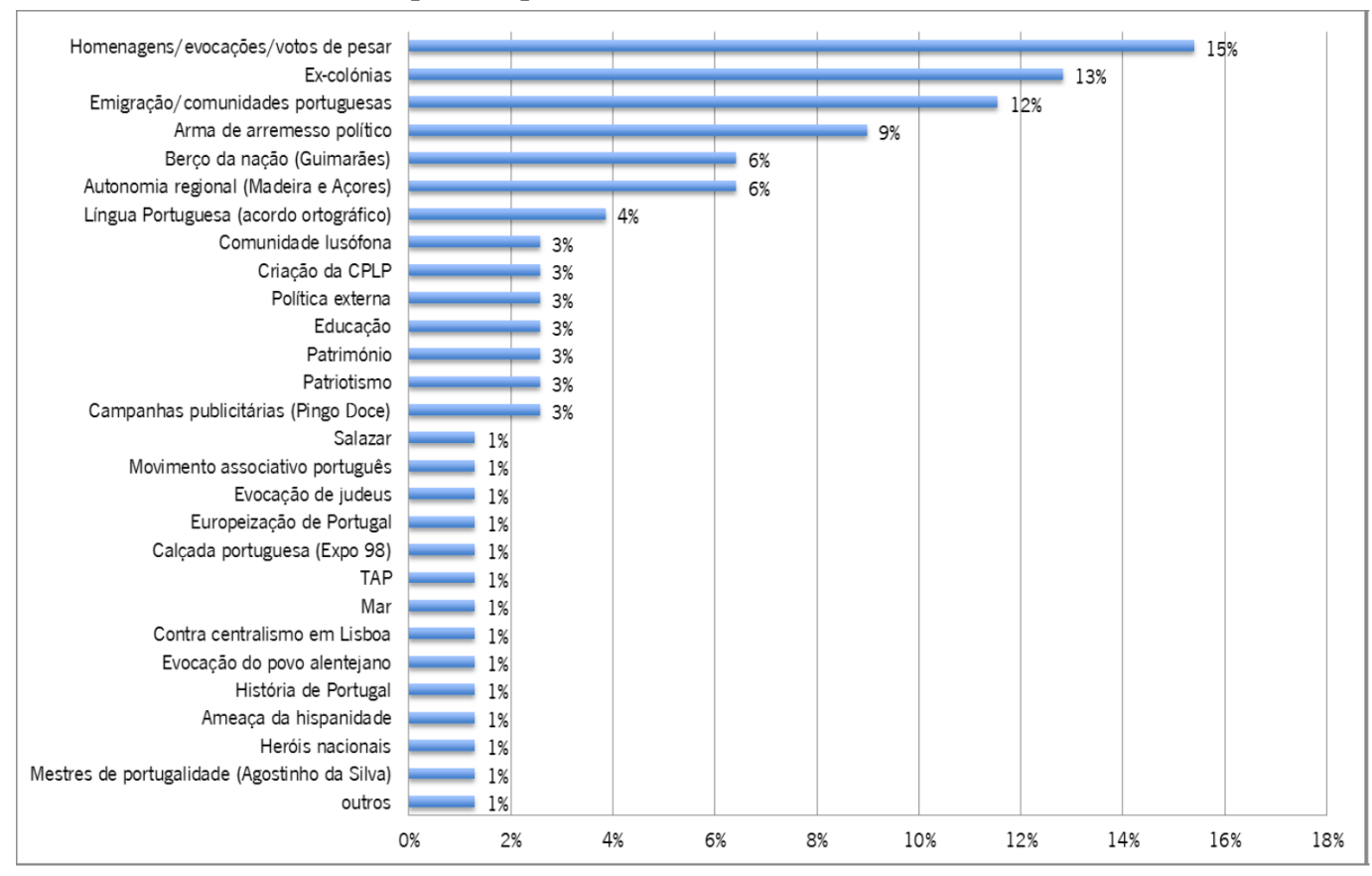

* Sousa, 2015, p. 212.

O termo começou a ser utilizado na AR em 1979, num discurso em que o deputado João Pulido (CDS) se referia a Torres Vedras como uma terra milenária que, no seu seio, "teve heróis defensores da portugalidade", que expulsaram "do solo pátrio o sanguinário invasor bonapartista e destroçado os seus exércitos que violenta e totalitariamente tentaram esmagar o luso povo" ${ }^{13}$.

A expressão é utilizada em 41 situações diferentes (em muitas delas, por mais do que uma vez), a maior parte das quais quando o assunto se refere a homenagens/evocações e votos de pesar, às ex-colónias, à emigração/comunidades portuguesas. Como já vimos, enquanto arma de arremesso político, mas também em relação à autonomia regional (Madeira e Açores), e à língua portuguesa/acordo ortográfico. Outras referências, quase sem expressão, podem ser encontradas associadas à 'portugalidade', como são os casos da comunidade lusófona, da criação da CPLP, da política externa, da educação, do património, do patriotismo e de mestres da 'portugalidade' (caso de Agostinho da Silva).

Da busca efetuada às bases de dados do Parlamento português, utilizando a palavra-chave 'portugalidade', entre 1976 e o fim da primeira sessão legislativa da II legislatura (14/9/2012), a expressão foi encontrada por 78 vezes, em 75 páginas, referentes a 66 diários. São os deputados do PSD os que mais utilizaram a expressão, destacando-se os casos de Lemos Damião (por seis

13. I Legislatura, sessão 3 de 11 de janeiro de 1979, incluída no diário de 12 de janeiro de 1979, p. 778. 
vezes), Carlos Encarnação (três), Rui Gomes da Silva e Margarida Silva Pereira (duas vezes cada um); seguem-se os deputados do PS e do CDS/PP, com destaque para os centristas Naraná Coissoró (por quatro vezes), Adriano Moreira e Nuno Abecassis (duas) e para os socialistas Manuel Alegre (quatro) e Capoulas Santos (duas). Do lado do PCP o deputado José Manuel Mendes utilizou a palavra por duas vezes; PPM e Bloco de Esquerda, ambos com duas e PSN e MDP/CDE, ambos com uma, fecham a contagem. Para além disso, a palavra foi utilizada por seis vezes por membros do Governo (quatro ministros e dois secretários de Estado) quando discursaram na AR.

\section{— Diferenças do Discurso Político sobre a 'Portugalidade' no Estado Novo e no Pós-25 de Abril}

Da análise à base de dados do Parlamento português, com os olhos postos na palavra-chave 'portugalidade', pode dizer-se que a sua utilização pelos deputados da AN e da AR nos seus discursos é quase residual (Sousa, 2015, pp. 215-227). Não obstante a conotação do termo ao Estado Novo, este é utilizado de forma transversal pelos deputados da AR - desde os ligados à denominada direita parlamentar, até aos pertencentes a partidos de esquerda, acérrimos contestatários do anterior regime -, e em sentidos diversos (ver gráfico 3).

Gráfico 3. Frequência da utilização da palavra 'portugalidade' na Assembleia da República por partido político (03-06-1976 a 14-09-2012)*

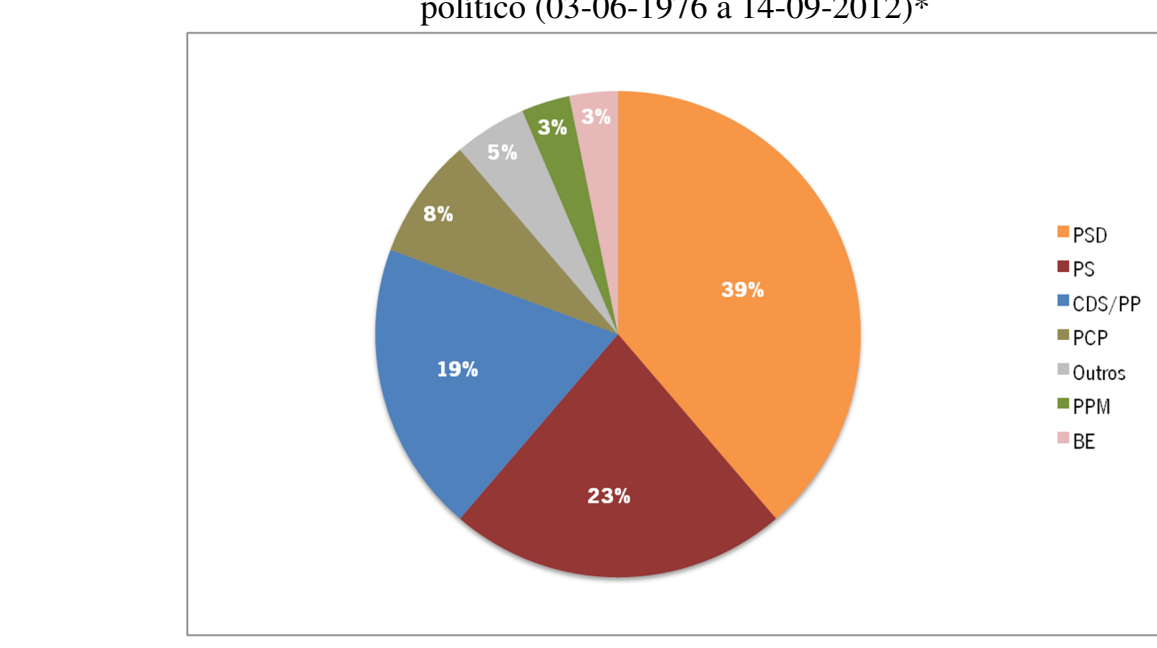

*A referência a 'Outros' diz respeito a membros de Governo ou a elementos da própria mesa do Parlamento que intervieram no hemiciclo (Sousa, 2015, p. 215).

Observaram-se dois momentos bem diferentes relativos aos discursos parlamentares: durante o período em que vigorou a ditadura (em que se tentou aferir a forma de como a retórica oficial assente na 'portugalidade' era vertida nos discursos dos deputados); e, em democracia (tentando vislumbrar eventuais diferenças com o período anterior e possíveis evoluções discursivas sobre a mesma matéria). O facto é que a maior parte dos temas dos discursos sobre os quais os deputados mais utilizam a palavra 'portugalidade' se cruza durante os dois períodos (ver gráficos 1 e 2). 
Na sequência desse levantamento, o foco foi colocado na legislação produzida relativa aos temas compartimentados. No caso da relação do Estado com as ex-colónias, por exemplo, teve-se em conta o facto de o "Ato Colonial" ter estado em vigor desde 1930 (substituindo o título V da Constituição de 1911 que vigorava até então), que já consolidava "um modelo colonial centralizado com medidas protecionistas, devendo o comércio colonial servir a acumulação do capital nacional" (Macedo, Maltez \& Henriques, 1999: 160). O decreto n. ${ }^{\circ} 18.570$ que lhe serviu de origem determinava ser "da essência orgânica da Nação Portuguesa desempenhar a função histórica de possuir e colonizar domínios ultramarinos e de civilizar populações indígenas" (Henriques \& Mello, 2007 [1989]: 231). Como vimos, no entanto, em 1951 com a revogação do "Ato Colonial", integrando-se as disposições constitucionais num capítulo intitulado "Do Ultramar Português", as "colónias" são substituídas por "províncias ultramarinas" e o Ministério das Colónias passa a chamar-se Ministério do Ultramar. No contexto das alterações constitucionais, a Carta Orgânica do Império Colonial Português foi substituída pela Lei Orgânica do Ultramar Português (1953), assumindo-se Portugal como um país uno e indivisível que se autodesignava "Portugal do Minho a Timor".

A palavra 'portugalidade' é, por conseguinte, um conceito contemporâneo, do slogan "Portugal do Minho a Timor", que se desenvolveu na sequência da revogação, como vimos, do "Ato Colonial", em que o Governo português passou a defender que Portugal seria um todo uno e indivisível, em que todas as colónias passaram a ser designadas por províncias, tal como as outras que existiam na 'metrópole'. Foi desenvolvida a partir daí, toda uma retórica destinada a sustentar um mito que apoiasse a ideia de que não haveria razões para o desenvolvimento de movimentos independentistas nos territórios portugueses de África e da Ásia. Não terá sido, então, por acaso que só nessa altura - 16 anos após o início da AN - que os deputados começaram a introduzir a palavra 'portugalidade' nos seus discursos, passando a AN a disseminá-la como eco da governação que especificamente era.

Segundo Moisés de Lemos Martins, o regime de 'verdade' salazarista reflete a sua própria ideologia, encenando a identidade nacional "segundo as metáforas de um acontecimento messiânico e distribuía-se de acordo com a lógica imposta pelo seu exclusivismo" (Martins, 1990: 141). Nesse sentido, no combate tendente a impedir a adulteração da 'verdade' da pátria é imposto um imaginário coletivo com o objetivo de preservar a unidade da nação, impedindo a sua fragmentação, através de ações destinadas à promoção da regeneração nacional, numa lógica profilática com vista a impedir a sua degenerescência (Martins, 1990: 105-124).

O discurso reflete, assim, "uma doutrina constante que consiste numa recta razão ordenada à natureza humana", assente no bom senso, ou "no equilíbrio natural das coisas" (Martins, 1990: 113) ou, como o próprio Salazar definira, a forma de se "viver habitualmente" em que a ambição deveria circunscrever-se à ideia de "ser autênticos na nossa modéstia" (Henriques e Mello, 1989 [2007]: 51), cuja interpretação decorre da expressão latina "aurea mediocritas", traduzida como "feliz mediania" e "bendita suficiência", ou seja, "viver feliz com o pouco que se tem, não aspirar a mais do que a uma vida mediana, não ter ambição" ${ }^{14}$. Não obstante, o próprio Salazar fazia questão de difundir a ideia de que "o Estado Novo português tem uma política ideológica"

14. Disponível em www.ciberduvidas.pt/pergunta.php?id=22469. Acesso em 05/12/2012. 
salientando que o estado sem ideologia era representado pelo "pretenso Estado liberal" (Salazar, 2007 [1937]: 41). E concretizava, referindo que "se o Estado é uma doutrina em acção, não seria lógico que se desinteressasse da sua própria ideologia", tendo mesmo a obrigação de "defendê-la e propagá-la, com vista à sua própria consolidação" (Salazar, 2007 [1937]: 41).

Mas a grande diferença que sobressai nos discursos parlamentares quando comparados o Estado Novo e o período do pós-25 de abril ocorre quando os temas versam sobre educação e juventude, e em que se sublinha, no primeiro caso, o papel da família - "célula social irredutível, núcleo originário da freguesia, do município e, portanto, da Nação: é, por natureza, o primeiro dos elementos políticos orgânicos do Estado constitucional" (Salazar, 1961: 93) -, que era privilegiado para ilustrar a 'portugalidade'. Em democracia, a associação à palavra 'portugalidade' passa a ser feita de forma quase residual, o que evidencia a mudança ideológica operada. O Estado Novo, através da propaganda do regime, fazia impor o mito do império particularmente através do sistema de ensino, com o próprio Salazar a deixar bem claro o que pensava sobre o papel da escola, sublinhando não compreender, nem poder admitir, que ela "não estivesse ao serviço da nação e não compreendesse o papel que lhe incumbe, neste momento de renascimento, de educar os portugueses ensinando-os a compreender bem e trabalhar bem" (Salazar, 2007 [1937]: 58-59). Por isso, o papel da escola destinava-se a tornar o espírito dos portugueses "forte para a luta", já que era necessário prepará-los para eventuais adversidades, "porque é preciso aceitar com calma os revezes da vida, suportar as agruras da adversidade, seguir com fé o seu destino, sacrificar-se pelo bem comum e sentir com lealdade, nobreza, perante a Pátria, o orgulho e a 'glória de sofrer'" (Salazar, 2007 [1937]: 60).

A este propósito, Luís Reis Torgal (2009) lembra que a publicação da lei no 1491 ("Remodelação do Ministério da Instrução Primária"), mais não foi do que uma espécie de lei de bases da "Educação Nacional". O Ministério da Instrução Primária passa a chamar-se Ministério da Educação Nacional, "designação que dizia respeito não apenas ao saber, mas a todo o processo moral e cívico da formação", criando-se assim a Junta Nacional de Educação (Torgal, 2009: 211). Era revelado, por exemplo, o cuidado a ter com o recrutamento de professores, nomeadamente em relação a aspetos de ordem política. Incluía um ponto que Torgal reputa como dos mais importantes, que apontava para a formação da Mocidade Portuguesa (MP), organização nacional e pré-militar, destinada a estimular "o desenvolvimento integral da sua capacidade física, a formação do carácter e a devoção à Pátria e a coloque em condições de poder concorrer eficazmente para a sua defesa" (Torgal, 2009: 212). Esta organização juvenil teve como modelo as organizações juvenis italianas, referindo que várias leis a ajudaram a sustentar, como foi o caso do regimento da Junta Nacional de Educação, de 19 de Maio de 1936 (decreto-lei no 26.611), em que se institui a MP, "que abrangerá toda a juventude, escolar ou não, e se destina a estimular o desenvolvimento integral da sua capacidade física, a formação do carácter e a devoção à pátria, no sentimento da ordem, no gosto da disciplina e no culto do dever militar" (Torgal, 2009: 214). Fernando Rosas salienta que toda a acção do regime era centrada "na formação do 'carácter', do 'gosto', do ideário dos portugueses", através de uma estética vanguardista, "originalmente casada com os conteúdos ideológicos conservadores do regime", como o "quotidiano das famílias, das escolas, das empresas, das aldeias, para o enquadramento dos lazeres, para a orientação ideológica da educação, da 
cultura e das artes" (Rosas, 2012: 181). O que ajuda a explicar que juventude e educação fossem das temáticas mais sublinhadas no que à 'portugalidade' diz respeito durante a AN.

Não será, por isso, de estranhar que, durante as sessões da AN haja referências aos missionários e aos professores como os grandes obreiros da 'portugalidade', decorrendo de um alinhamento estreito com a política em vigor. No entanto, não obstante a mudança verificada entre o período do Estado Novo quando comparado com o do pós-25 de abril em relação à utilização do termo ligado à educação, o facto é que há pelo menos uma referência de um deputado que usa o epíteto "irradiadores de "portugalidade" em relação aos "cooperantes" portugueses nas ex-colónias (sendo muitos deles professores).

Nos discursos dos deputados da AR há, também, várias tentativas de definição da palavra 'portugalidade' que, paradoxalmente, não fogem do conceito utilizado pelos parlamentares da AN. No período pós- 25 de abril, isso acontece na sua maioria por parte dos deputados da denominada 'direita parlamentar', casos de Narana Coissoró, Rui Gomes da Silva, Fernando Nogueira e Vieira de Carvalho. A exceção cabe ao socialista Manuel Alegre, que é o único deputado da ala esquerda a utilizar a palavra 'portugalidade' de uma forma sublinhada, salientando mesmo que não deveria existir medo em pronunciá-la, nomeadamente no que ela tem de mais perene, referindo-se à língua, à poesia e à cultura. Alegre sublinha mesmo a vocação humanista e antirracista como características da 'portugalidade'. O que levará, então, um deputado como Manuel Alegre, um lutador antifascista que esteve exilado durante o Estado Novo, regressando a Portugal após a Revolução do 25 de abril, a defender acerrimamente um termo associado ao regime salazarista? De resto, não existe qualquer tipo de relação entre a 'portugalidade' de Manuel Alegre e a do monárquico Alfredo Pimenta, autor do livro "Em Defesa da Portugalidade".

Também se notam diferenças entre as escolhas dos deputados do Estado Novo e os do período pós-25 de abril, quando a palavra foi utilizada em evocações. No primeiro caso, recaíram em protagonistas do sistema vigente; depois, paradoxalmente, em personalidades quase todas ligadas à luta antifascista; alguns desses vultos, não deixaram de ser evocados, mesmo tendo presente a sua ideologia de certa forma alinhada com o anterior regime, como foi o caso de António Quadros (pertenceu ao Grupo da Filosofia Portuguesa na companhia de Álvaro Ribeiro, José Marinho, Afonso Botelho, Cunha Leão, Dalila Pereira da Costa e outros pensadores). A referência à 'portugalidade' no caso do voto de pesar pela morte de José Saramago, da autoria da então ministra da Cultura, Gabriela Canavlhas, dará que pensar, não obstante Ana Paula Arnaut, da Universidade de Coimbra, sustentar que o escritor teve um primeiro ciclo "caracterizado por marcas de "portugalidade intensa', directa ou indirectamente enraizado na realidade portuguesa" (Coutinho, 2008: S/P). Bastará, no entanto, ter em mente A JANGADA DE PEDRA para questionarmos a dinâmica do escritor em relação à 'portugalidade' a que o associaram no parágrafo anterior.

De resto, não há qualquer referência à palavra 'portugalidade' ligada à evocação do $10 \mathrm{de}$ junho (mesmo tendo presente que as sessões parlamentares nunca se realizaram nesse dia por ser feriado) - no caso da AN, em que se assinalava o "Dia da Raça" e, depois do 25 de abril, na AR, como "Dia de Portugal, de Camões e das Comunidades Portuguesas" -, o mesmo acontecendo a propósito da realização da "EXPO'98 - Exposição Mundial de 1998”, e em que se evocou de forma sublinhada Portugal e os Oceanos. Nesse ano, apenas por uma vez foi utilizada a expressão 
'portugalidade' e não foi diretamente por causa desse evento, mas numa intervenção em que uma deputada a ela se referia como palco da divulgação da calçada portuguesa como ex-libris do país.

Um dos cultores da 'portugalidade' foi o ex-presidente da República, Cavaco Silva, que não viu problemas em utilizar o termo em circunstâncias aproximadas em que ele era usado durante o Estado Novo ${ }^{15}$. A este propósito, Miguel Cardina, na observação que fez dos discursos políticos proferidos pelo ex-Presidente da República entre 2006 e 2014, nas sessões comemorativas do 25 de Abril e do 10 de Junho, evidencia "como este tipo de 'memória oficial' tem vindo a accionar certas narrativas sobre o passado que reinterpretam a natureza e o lugar do colonialismo, das guerras coloniais e da descolonização no processo histórico contemporâneo" (Cardina, 2014: S/P). Num texto publicado no portal Buala, intitulado "O colonialismo nunca existiu?", o investigador identifica a presença de cinco tópicos relativos à questão colonial no discurso de Cavaco Silva: o da "imaginação da colonização como tendo consistido essencialmente num encontro de culturas"; a "evocação do "universalismo português"”; a "identificação da língua, da cultura e do património como os produtos históricos desta 'vivência universalista' dos portugueses, ao qual é também associada a familiaridade com o Mar"; a definição de Portugal como país europeu "que então empreende a aventura colonial"; e "o silêncio sobre a guerra colonial - que é, no fundo, um silêncio sobre o fim do Império e os antecedentes do 25 de Abril” (Cardina, 2014a: S/P). Segundo o investigador, estes tópicos "apontam para a persistência de um imaginário de traços coloniais num espaço-tempo pós-colonial", sendo que nos discursos do Presidente da República, a questão colonial "é deslocada através de um mecanismo que omite os processos históricos ligados ao racismo, à escravatura e à dominação económica e cultural" e que, em alternativa, "realça o papel da língua, do património e do Mar como elementos diferenciadores da experiência colonial portuguesa" (Cardina, 2014a: S/P), numa narrativa que embora não seja nova, reproduz um conjunto de tópicos de matriz "lusotropicalizante". E, recorrendo ao título de uma coletânea de textos de Eduardo Lourenço sustenta que "os discursos de Cavaco Silva parecem assim demonstrar a permanência do colonialismo como um 'nosso impensado"" (Cardina, 2014a: S/P). Miguel Cardina voltaria ao assunto já em 2017, num artigo também publicado no Buala, intitulado "Enfrentar os fantasmas presentes".

15. A nossa investigação já tinha mapeado as intervenções do Presidente da República, Cavaco Silva, em que este utilizou a palavra 'portugalidade' numa logica lusotropicalista (Sousa, 2015). Assim, em 2008, no "Dia de Portugal, de Camões e das Comunidades Portuguesas" realizado em Viana do Castelo, Cavaco Silva escusou-se a comentar determinada notícia com a justificação de que estava "a presidir ao 'Dia da Raça"” [http://tinyurl.com/mmc78sc]; Em 2009, em comemorações análogas (Santarém), apelou "ao 'espírito de portugalidade', prometendo continuar a contribuir para que os emigrantes aumentem a sua participação cívica e política nos 'tempos incertos que vivemos"” [http://tinyurl.com/7hqe82s]; Em novembro de 2012, a propósito do mau tempo no Algarve, referia ao Diário de Notícias que "todos aqueles que ajudaram nas tarefas de limpeza em Silves e Lagoa nos dias que se seguiram ao temporal 'deram uma emocionante lição de portugalidade solidária' ao país” [http://tinyurl.com/mb89apq]; Em 2013, de novo no "Dia de Portugal, de Camões e das Comunidades Portuguesas" (Elvas), numa comunicação deixada no portal da Presidência da República, associava a 'portugalidade' à diáspora [http://tinyurl.com/q3ghgm4]; Em 2015, no Dia de Portugal, de Camões e das Comunidades Portuguesas (Lamego), deixa uma mensagem no portal da Presidência da República, em que se refere à 'portugalidade' na diáspora: "Desde que tomei posse como Presidente da República, sempre procurei sublinhar o orgulho que nos inspiram os Portugueses da Diáspora e o muito que fazem para projetar, por todo o mundo, a imagem do Portugal inovador e empreendedor que devemos continuar a edificar. São verdadeiros embaixadores da portugalidade" [hrefhttp://tinyurl.com/oqsb2jnhttp://tinyurl.com/oqsb2jn]. 
O assumir de funções de Marcelo Rebelo de Sousa como Presidente da República fez prosseguir de forma sublinhada a utilização da 'portugalidade' no discurso político no quadro daquele órgão de soberania. Na tomada de posse do cargo, já tinha ameaçado fazê-lo (embora a ela se não tenha referido diretamente), evocando passagens da denominada 'história mítica de Portugal', onde pontificam, por exemplo, o 'Milagre de Ourique', as 'Cortes de Lamego', que Alexandre Herculano desmontou mas que, anos depois, o Estado Novo recuperou e não se cansou de disseminar, através da sua propaganda. O mesmo aconteceu com as figuras de Viriato e Nun'Álvares Pereira, tornados símbolos da 'portugalidade' e da independência nacional. Para o historiador Diogo Ramada Curto o facto de Marcelo Rebelo de Sousa convocar toda essa parafernália mítica constituiu um somatório de "referências obsoletas, para não lhes chamar bacocas". E fez um reparo: "Imagino como terá sido entendida, pelo Presidente de Moçambique, a frase não identificada de Mouzinho de Albuquerque, que capturou Gungunhana em Chaimite, 'este Reino é obra de soldados'!". Mas também viu coisas positivas no discurso do Presidente, como a menção explícita ao que foi o 'Império Colonial', "uma expressão - como diz -, de que muitos têm medo, na qual se reconhece um modo de enterrar o passado, em lugar de o comemorar" (Gomes, M. \& Crisóstomo, P., 2016).

Já no elogio fúnebre de Mário Soares, utilizou a palavra 'portugalidade' para caracterizar o ex-Presidente da República, reputando-o de humanista, mas associando-a a utilização da palavra ao patriotismo e afirmando que ele tinha sido "um construtor de portugalidade". Uma afirmação constante do discurso de Marcelo Rebelo de Sousa, por escrito, desenvolvida mesmo tendo em conta que o ex-Presidente tivesse estado na linha da frente para derrubar o Estado Novo e da correspondente 'portugalidade' em que ele assentava, tendo pago caro essa ousadia, nomeadamente através da deportação e do exílio. No discurso, com pouco mais de sete minutos e que está disponível no sítio da Presidência da República, Marcelo Rebelo de Sousa utiliza oito vezes a palavra 'portugalidade' (Presidência da República, 2016).

Num outro registo, a 'portugalidade' esteve na origem de uma polémica recente que envolveu a Faculdade de Ciências Sociais e Humanas (FCSH) da Universidade Nova de Lisboa e a Associação Nova Portugalidade. Tudo a propósito do cancelamento de uma conferência, por parte da FCSH, do historiador Jaime Nogueira Pinto, promovida pela referida associação, intitulada "Populismo ou Democracia? O Brexit, Trump e Le Pen". Para os organizadores, tratou-se de um ato de censura, enquanto a associação de estudantes da Faculdade, salientava tratar-se do repudiar de um evento nacionalista e colonialista. Na página do Facebook ${ }^{16}$ da 'Nova Portugalidade', pode ler-se que "somos 250 milhões", que "a unir-nos temos sangue e séculos, cultura e sentimentos", e que "a sugerir a reaproximação entre nações de fala lusa está (...) a necessidade - que é justa e natural - de reerguer uma família de povos que só por trágico equívoco se desfez", o que não deixa dúvidas em relação à ligação ideológica da referida entidade. No seguimento deste cancelamento foi promovida uma manifestação a favor da 'Nova Portugalidade', por parte do Partido Nacional Renovador e uma contra-manifestação, numa ação da responsabilidade dos alunos da FCSH da Universidade Nova de Lisboa. O assunto trouxe ao de cima a temática da 'portugalidade' e da sua associação ao Estado Novo, provocando uma acesa discussão nomeadamente nos média e nas

16. Disponível em http://tinyurl.com/ma9ou5b 
redes sociais, em que o enquadramento sobre a Nova Portugalidade a ligava à (velha) 'portugalidade' estado-novista. Na sua grande maioria, quase nenhum articulista dos média perdeu tempo com as atualizações da 'portugalidade', preferindo fixar-se na matriz original do seu cunho, mas daí lembrando a perigosidade da ligação a conceitos em vigor durante o fascismo ${ }^{17}$. Este episódio motivou mesmo a intervenção do Presidente da República, Marcelo Rebelo de Sousa, que exigiu da universidade um esclarecimento para o cancelamento da conferência de Jaime Nogueira Pinto, e também os efeitos decorrentes de uma decisão dessas. Na altura, Marcelo Rebelo de Sousa afirmou que "o Presidente da República é o guardião dos direitos constitucionais, entre eles a liberdade de expressão. Por isso, para mim é incompreensível uma decisão daquelas por parte de uma instituição pública, como é uma faculdade pública". Apelidou a decisão dos responsáveis da FCSH de "absurda", sublinhando o contraste entre a decisão de uma instituição pública, como é o caso da FCSH, e a Associação 25 de Abril que, face ao cancelamento da iniciativa no estabelecimento de ensino, disponibilizou as suas próprias instalações para servir de palco ao debate que foi cancelado, "lembrando-se do que significou o 25 de Abril"de 1974, que "foi feito precisamente para consagrar a liberdade e a democracia" ${ }^{18}$. Horas depois da tomada de posição do Presidente da Republica, a instituição, em comunicado, sustentou que a conferência foi adiada para que o tema proposto pudesse ser discutido "de forma alargada e objetiva num clima sereno", esperando por "condições de completa abertura e diálogo plural"para a realização do evento ${ }^{19}$.

\section{A Memória Coletiva e a História}

Eduardo Lourenço observa que o passado também se inventa, pelo que refere preferir um presente com memória, ela própria condição de futuro, porque como escreve justamente em Nós como Futuro, "povo sem memória não tem futuro. Mas para isso, terá de reviver o passado como memória activa. Sempre em revisitação e mesmo em invenção" (Lourenço, 1998: 30-31). Acrescenta que Portugal sofre de hiperidentidade, por ter um défice de identidade real que compensa no

17. De um vasto rol de artigos saídos nos média, quase todos os autores fazem a associação da 'portugalidade' ao Estado Novo, sublinhando um alegado recorte fascista na base do que se passou relativamente ao cancelamento da conferência de Jaime Nogueira Pinto na FCSH: A "crispação"e os "patriotas", Manuel Loff (Público, 18-03-2017). Retirado de https://tinyurl.com/mjqcgjt; Multiculturalismo, Miguel Sousa Tavares (Expresso, 18-03-2017, p. 7); Tão felizes que nós éramos, Clara Ferreira Alves (Revista E, Expresso de 18-3-2017, p. 2); O império contra-ataca. Alexandra Lucas Coelho (Público, 13-03-2017). Retirado de https://tinyurl.com/kuyracb; Esta "Portugalidade"nova que nos pastoreia, João Gonçalves (Jornal de Notícias, 13-03-2017). Retirado de https://tinyurl.com/keyvv68; Uma Nova Portugalidade, Raquel Varela (Página pessoal de Raquel Varela, 10-03-2017). Retirado de https://tinyurl.com/lwwh8yw; FCSH, indignações e silêncios, José Soeiro (Expresso online, 10.03.2017). Retirado de https://tinyurl.com/19s8652; Velha portugalidade, Rui Tavares (Público, 10-03-2017,). Retirado de https://tinyurl.com/m5hareg; Liberdade de expressão? Dia sim, dia não..., Francisco Teixeira da Mota (Público, 10-03-2017). Retirado de https://tinyurl.com/m9faxov; Vinte e quatro palermas e um director medroso, João Miguel Tavares (PúBLICO, 09-03-2017). Retirado de https://tinyurl.com/lkxbnzz; Faculdade de Ciências Parvas e Trolitanas?, Ferreira Fernandes (Diário de Notícias, 07-032017). Retirado de https://tinyurl.com/lncazvs; Macroscópio - O definhar do espírito crítico, José Manuel Fernandes (Observador, 07-03-2017). Retirado de https://tinyurl.com/kfjjdyo.

18. Retirado de www.jornaldenegocios.pt/economia/politica/detalhe/marcelo-considera-absurdo-cancelar-conferen cia-de-nogueira-pinto-e-quer-explicacao

19. Retirado de http://rr.sapo.pt/noticia/77899/reitoria_da_universidade_nova_rejeita_ameaca_a_liberdade_de_exp ressao 
plano imaginário (1994 [1988]). O que nos conduz à história mítica de Portugal, e ao imaginário que lhe está subjacente. O que parece mais complicado é compreender o estado de evidência que torna possível a assimilação inconsciente de tais "invenções", que penetram e irrompem em solo intelectual e político diverso. É, afinal, segundo Bruno Monteiro e Nuno Domingos (2015) a ideia de "povo" que está em questão e que constitui um ponto de encontro para as visões do mundo opostas, porém complementares, que caracterizam o miserabilismo e o populismo que, em Portugal, inspiram correntes de pensamento que se pensam e se mostram como incompatíveis e inconciliáveis. A este propósito, José Mattoso não deixa dúvidas ao sublinhar que se o critério de análise de toda esta problemática for o da objetividade, excluem-se desde logo as teorias míticas e messiânicas, "tão insistentes, tão carregadas de emotividade, acerca do destino universal do povo português, do seu insondável 'mistério' e da sua irredutível originalidade" (Mattoso, 2008: 97).

Entre a 'portugalidade' mítica e a que se encontra no domínio da política, ainda há quem reabilite a lógica de um 'regresso de caravelas'. Eduardo Lourenço (1954) refere que a existência mítica precede a existência empírica; já Roland Barthes (1978 [1957] olha para o mito como conversor da história em natureza e o contingente em eternidade; por seu turno, Pierre Bourdieu (1982) sustenta que não é o mito que dá forma à história.

Sanjay Subrahmanyam rejeita a ideia de que a principal função do historiador seja lembrar, já que o trabalho se desenvolve em sentido contrário à dinâmica de acreditar na memória, indo mesmo contra ela, uma vez que se revela falsa (Meireles, 2016, p. 50). Paul Ricoeur, no livro $A$ memória, a história e o esquecimento (2000), ao confirmar a inseparabilidade entre a memória e o esquecimento, observou que este último reveste uma forma negativa e outra positiva. Por um lado, existe uma forma negativa de esquecimento, irreversível e destruidor, que, na história, corresponde à perda de documentos e ausência de fontes, e contribui para uma memória patológica. Para o seu desenvolvimento contribuem duas atitudes negativas diversas: a "insuficiência", que se deve a uma atitude de fuga e negação dos momentos traumáticos do passado, através da qual se está, de forma paradoxal e incessantemente condenado a revivê-lo. Este reviver incessante, doloroso e traumático, através de um "excesso de memória", é a outra atitude negativa. Há, por outro lado, uma forma positiva de esquecimento e que Ricoeur designou como um esquecimento de "reserva", que, ao erguer-se "contra o esquecimento destruidor", tem o condão de "preservar" (Ricoeur, 2000). O historiador espanhol Fernando Bouza refere-se a um ditado africano, que diz que "a memória vai ao bosque buscar lenha e traz de lá a lenha que quer" (Canelas, 2014). O que significa que cada um de nós é feito de fragmentos e a nossa identidade é um somatório de memórias sobrepostas, sendo que um lugar, por exemplo, não é de um tempo só. Eduardo Lourenço afirma que "um tempo é todos os tempos. Não antecipa só o futuro. Recicla todos os passados" (Lourenço, 1998). Já Eric Hobsbawm lembra, a este propósito, que "a maioria dos seres humanos atua como os historiadores: só em retrospecto reconhece a natureza de sua experiência" (Hobsbawm, 1995: 252). Ora, Umberto Eco afiança que o que torna os signos interessantes não é o facto de eles servirem para dizerem a verdade, mas poderem ser usados para mentir. Daí que defenda que as pessoas prefiram a mentira à verdade (Leiderfarb, 2015). Numa entrevista ao Público, o escritor Luís Fernando Veríssimo afirmava mesmo que "a mentira é uma necessidade social" (Coutinho, 2016). 
São, pois, bem observáveis as consequências das práticas desenvolvidas no século XX relativas a todos os tipos de particularismo, em que a "exclusão do outro" tem moldado uma história catastrófica que, como refere Chris Lorenz (2010), hoje se enfrenta.

Tal como observa Stefan Berger, tendo por base a ideia de que a segunda metade do século $\mathrm{XX}$ foi testemunha de movimentos de sentido pós-nacionalista, as historiografias permanecem firmemente estruturadas ao longo das linhas nacionais. Se alguém se referir ao revivalismo do paradigma nacional na Europa ou ao surgimento de uma narrativa pós-clássica nacional após 1989, "as histórias nacionais ainda formam a maior parte do que os historiadores escrevem sobre a atualidade e que tem uma relevância mais ampla para além dos limites da academia" (Berger, 2006: 3). A europeização e a globalização questionam o sentido das narrativas puramente nacionais, mas os mesmos processos também têm causado uma reação defensiva para muitas pessoas que se apegam às "suas" narrativas nacionais, na esperança de combaterem os efeitos de tais tendências. Isso é mais visível nos movimentos radicais de direita em toda a Europa, que "estão a tentar instrumentalizar as versões das histórias tradicionais e familiares nacionais para reforçar as suas aspirações políticas" (Berger, 2006: 3). No entanto, não é só a direita radical que utiliza a história nacional na busca de objetivos políticos e de apoio, com os partidos de centro-direita e de centro-esquerda tradicionais a também fazerem uso de passados nacionais. Como lembra Daniel Woolf (2006), a historiografia é global sendo necessário algum tipo de arcaboiço teórico que identifique os principais conceitos, temas e termos que podem ser encontrados em várias historiografias. Não obstante, muito embora a globalização relativize as influências dos estados e a sua própria soberania, em tempo de crise emergem os apelos ao patriotismo e os nacionalismos (Sousa, 2014).

O certo é que se constata uma lógica luso-tropicalista no discurso, nomeadamente dos políticos. Cláudia Castelo (2010 [1999] \& 2013) refere que o estudo de receção do luso-tropicalismo em Portugal dá uma ajuda na perceção de como as ideias de Gilberto Freyre ainda ecoam no atual discurso político e cultural. Diz, no entanto, que o risco atual reside no facto de o conceito continuar a ser usado de forma acrítica e imobilista. Se, no passado, serviu para legitimar o colonialismo português, hoje é utilizado para dar corpo ao mito da tolerância racial dos portugueses e até de um nacionalismo português integrador e universalista, em contraponto aos 'maus' nacionalismos, fechados, etnocêntricos e xenófobos. Miguel Cardina (2016) chama a isto neo-lusotropicalismo, propondo "enfrentar os fantasmas presentes".

Já Jacques Le Goff (1984) referira que os esquecimentos e os silêncios da história são reveladores destes mecanismos de manipulação da memória coletiva. O que significa que ainda se olha para a História como se ela fosse construída entre bons e maus e ela é muito mais complexa do que isso. No caso específico português, continua-se a escrever - muito embora muito menos do que antes -, sobre os feitos gloriosos dos navegadores e dos grandes heróis da nação, sobrevalorizando-se, por exemplo, os efeitos dos contactos luso-africanos (basta atentar nos estudos feitos em relação aos manuais escolares) (Cruz, 2015).

A naturalização de diversas narrativas mestras são legitimadas pela produção científica, sendo que as construções que se fazem apresentam como universal o que resulta de uma posição social e política particular, como salientam Bruno Monteiro e Nuno Domingos: 
Louvamos, invocamos, rimo-nos, acusamos, envergonhamo-nos ou vituperamos a imagem de "portugalidade"que nós próprios, "nós, os portugueses", vemos reflectida pelo espelho da nossa consciência. Por viciado que seja o espelho, a imagem que ele nos traz de volta pode sempre parecer-nos "verdadeira", "autêntica", "idêntica". A forma do espelho, porém, é que plasma e que fixa a imagem em que aprendemos a reconhecer-nos e a conformar-nos como o que somos. (...) Ao invés, permanecemos usualmente impávidos e imperturbáveis perante a imagem que nos habituamos a mostrar e a tomar, ingénua e convictamente por "natural"(2015: 14).

José Neves observa que o relato historiográfico está condenado a usar palavras do passado e de hoje, sendo que "o problema não reside na circunstância de um historiador discursar sobre sujeitos de um dado período fazendo uso de nomes próprios de outros períodos no que consubstancia um anacronismo; o problema surge quando o historiador não o circunstancia (...) nem discute tal intertextualização" (2016: 14). José Manuel Sardica tem uma perspetiva equidistante tanto do velho cientismo positivista quanto do relativismo radical da pós-modernidade. Sustenta que, nos dias de hoje, já ninguém acredita que a história e passado são a mesma coisa, advertindo no entanto, que "a história é uma construção mental sobre o passado" (Sardica, 2016: 77) e que, a partir desse passado, mesmo que tenha que renunciar ao conhecimento total, fixo e imutável do positivismo, nem por isso o historiador "deve aceitar a inversão total da epistemologia" (Sardica, 2016: 77-78). Pedro Cardim faz notar que a forma como se olha para a História está a mudar, sendo que ainda há duas décadas "predominavam as interpretações essencialistas e a-históricas, as simplificações maniqueístas e ainda as desconfianças motivadas por sentimentos xenófobos que só produziam incompreensão e rancor" (Cardim, 2014, S/P).

\section{Conclusões}

Qual o sentido que a 'portugalidade' tem hoje? Será que as ideias de Alfredo Pimenta ainda pontuam o conceito? Ou o ideário luso-tropicalista fixado por António Ferronha pode ser a sua melhor tradução? Se a 'portugalidade' não corresponder a qualquer conceito, mas se a sua utilização for justificada pela ideia de que o sentido é o uso (Wittgenstein, 1958) para que se possa 'validar' enquanto tal, para que servirão, afinal, os conceitos? Porque é que a 'portugalidade' não se assume enquanto conceito? $\mathrm{O}$ facto de nenhum dicionário dito de referência por nós compulsado ter qualquer entrada com a palavra 'portugalidade', torna problemática a 'validação' da utilização do termo. Intrigante é o facto de isso ter acontecido mesmo no período do Estado Novo, durante o qual a palavra emergiu.

E, mesmo que hoje seja menos plausível a existência de particularismos dos povos, e não haja lugar para qualquer espécie de 'portugalidade' ${ }^{20}$ - pelo menos no sentido em que ela foi forjada -, o termo é cada vez mais utilizado, ao contrário do que poderia ser expectável. A 'portugalidade' é utilizada com o foco virado para a melhoria da autoestima dos portugueses, o que é muito observável na área da publicidade e do marketing. A confirmá-lo, está o "Estudo de Portugalidade,

20. Declarações proferidas por Eduardo Lourenço em entrevista à RTP (Grande Entrevista, 10/6/2015) [47’00 47'55] Retirado de http://tinyurl.com/pnawtew 
Hábitos de Consumo e Notoriedade da Marca Portugal Sou Eu", coordenado por Helena Martins Gonçalves (Instituto Superior de Economia e Gestão/Centro de Estudos de Gestão), apresentado durante o primeiro Fórum do movimento "Portugal Sou Eu" que decorreu no dia 27 de novembro de 2014, no Centro de Congressos de Lisboa, em que logo o primeiro ponto destacado foi a 'portugalidade'. O documento, que resulta de um estudo com 1301 respostas válidas, refere que o conceito de 'portugalidade', associado ao momento em que os inquiridos pensam em Portugal, está ligado a valores como a tradição, a segurança, as relações calorosas, o ser respeitado (reputação em alguns domínios), a liberdade, e a alguns produtos como o vinho, o azeite, o peixe, o pastel de nata/de Belém e o bacalhau ${ }^{21}$. Há quem faça corresponder a 'portugalidade' à expressão "Made in Portugal", como é o caso da consultora Augusto Mateus \& Associados que, em janeiro de 2013, a pedido do jornal "Expresso", identificou os melhores produtos feitos em Portugal olhando ao peso nas exportações, presença nos mercados mundiais, inovação e sustentabilidade (Santos, 2013: S/P). Quase dois anos depois, no mesmo jornal, publicava-se uma reportagem no suplemento de Economia, intitulada "Mais português não há", em que já era naturalizado o conceito de 'portugalidade' com base na tipificação efetuada pela referida consultora, entretanto também adotada pelo movimento "Portugal sou eu". Assim, a propósito de uma empresa de enchidos de Bragança, que utiliza na sua produção apenas $4 \%$ de especiarias espanholas, referia-se que o presunto produzido pela empresa tinha "96\% de portugalidade" (Pereira, 2015: 16)...

E, não obstante, no domínio do branding, se apostar muito na "marca Portugal", trata-se de uma generalização que, segundo o gestor cultural Miguel Magalhães, "mais não é do que simplificar o que não é simplificável", sendo que "a cultura de um país, os seus artistas e uma história acumulada não cabem dentro de nenhuma marca" (2014, S/P).

De resto, os portugueses continuam a sublinhar, através de vários inquéritos periodicamente divulgados, que não têm problemas de identidade. O facto é que as clivagens provocadas pelo termo 'portugalidade' na sociedade portuguesa ainda se fazem sentir, permanecendo a sua associação ao Estado Novo, período durante o qual foi forjado, o que se pôde observar ainda recentemente com o caso descrito sobre a Associação Nova Portugalidade.

Mas, tal como a identidade, a 'portugalidade' não pode ser reificada, já que estando integrada na sociedade, decorre das mudanças aí operadas. Também a 'portugalidade', encarada numa perspetiva dinâmica, deve ser 'limpa' dos equívocos em que assenta. E, de todas as tentativas em tipificar o conceito, aquele que nos parece mais consentâneo com a realidade é, precisamente o que contextualiza a sua génese e interpreta o sentido da sua utilização atual, mesmo deixando de fora toda e qualquer clivagem que vá no sentido da existência de um eventual racismo cultural, como refere Stuart Hall (2000 [1992]) a propósito da englishness, e o não faça assentar em qualquer essencialismo que lhe esteve na origem. Ou seja: deslocando-o da lógica nacionalista, em que foi forjado, e balizando-o no patriotismo, um sentimento muito mais benigno e razoável, segundo Eduardo Lourenço (1989: 8-9). Como parece ser o caso, de resto, do presidente da República, Marcelo Rebelo de Sousa, que utiliza a palavra 'portugalidade' nas suas alocuções públicas de uma forma aparentemente diferente da do seu antecessor, não obstante a família política de ambos ser a mesma. O atual Presidente da República incorre, no entanto, também ele em equívocos ao

21. Retirado de http://tinyurl.com/oyzgdk9 
querer associar à lógica da 'portugalidade' personalidades que contra ela combateram, como foi o caso de Mário Soares e sobre quem, Marcelo Rebelo de Sousa, fez um discurso fúnebre em que o tipificava como protagonista da 'portugalidade'. Decerto, não teve a intenção de o associar ao Estado Novo, nem a toda a dinâmica subsequente, mas esta tipificação não deixou de ser um contrassenso.

A desmistificação da história permitiu que se desse um passo em frente na investigação nomeadamente em relação às identidades nacionais, passando a contextualizar-se os acontecimentos e a separá-los da mitologia. Ou, como bem sintetizam Miguel Bandeira Jerónimo e José Pedro Monteiro (2017), "o debate decorre maioritariamente da memória e da política, não da história", o que provoca muitos equívocos, já que isso "pouco contribui para a obrigação cívica que todos temos: discutir de modo rigoroso e crítico, sem preconceitos e sem cedências, os passados do presente. $\mathrm{E}$ os caminhos do futuro que queremos".

\section{Referências Bibliográficas}

Barthes, R. (1978 [1957]). Mitologias. Lisboa: Edições 70.

Berger, S. (2006). National Historiographies in Transnational Perspective: Europe in the Nineteenth and Twentieth Centuries. Storia della Storiografia, 50, 3-26.

Bom, J. C. (2000). Portugalidade, pergunta-resposta. Ciberdúvidas da Língua Portuguesa, 7/4/ 2000. Retirado de http://tinyurl.com/2uanuhv

Bourdieu, P. (1982). Ce que parler veut dire: l'économie des échanges linguistiques. Paris: Fayard.

Brito, A. J. (1982). Do pensamento de Alfredo Pimenta. Boletim de Trabalhos Históricos, XXXIII: 103-116.

Canelas, L. (2014, 14 de dezembro). Entrevista ao historiador Fernando Bouza "O Portugal dos Filipes é uma criação portuguesa". Público. Retirado de http://tinyurl.com/19kvxbj

Cardim, P. (2014). Portugal, Catalunha e Espanha ou o uso que o nacionalismo faz da história. Público, 25/2/2014. Disponível em www.publico.pt/cultura/noticia/portugal-catalunhae-espanha-ou-o-uso-que-o-nacionalismo-faz-da-historia-1626114. Acesso em 25/2/2014.

Cardina, M. (2014). O lugar do colonial nos discursos de Aníbal Cavaco Silva. Comunicação apresentada no IX Congresso Ibérico de Estudos Africanos. Retirado de http://tinyurl.com/of alyn7

Cardina, M. (2014a). O colonialismo nunca existiu?. Retirado de ttp://tinyurl.com/qfwwbzw

Cardina, M. (2016). Memórias amnésicas? Nação, discurso político e representações do passado colonial. Configurações, 17: 31-42.

Cardina, M. (2017, 18 de outubro). Enfrentar os fantasmas presentes. Buala. Retirado de www.buala.org/pt/a-ler/enfrentar-os-fantasmas-presentes

Castelo, C. (2011 [1999]). O modo português de estar no mundo. Porto: Edições Afrontamento. 
Castelo, C. (2013). O luso-tropicalismo e o colonialismo português tardio. Retirado de http://tiny url.com/p2kyd9r

Costa, J. A. \& Melo, A. S. (1994). Dicionário da Língua Portuguesa. Porto: Porto Editora.

Costa, J. A. \& Melo, A. S. (1965). Dicionário da Língua Portuguesa. Porto: Porto Editora.

Coutinho, I. (2008). Saramago, o escritor que brinca com a pontuação. Público, 23/4/2008. Disponível em http://tinyurl.com/2f8flsu. Acesso em 11/10/2010.

Coutinho, I. (2016, 29 de novembro). Entrevista a Luís Fernando Veríssimo: Fora a mentira política, criminosa até, a mentira é uma necessidade social. Público, Retirado de http://tinyurl.co $\mathrm{m} / \mathrm{nyxe} 27 \mathrm{w}$

Cruz, M. B. (2008). Prefácio. In Salazar e Alfredo Pimenta, Correspondência 1931-1950 (pp.526). Lisboa: Verbo.

Cruz, V. (2015, 28 de março). Fazedores de passados. Expresso, pp. 64-65.

Derrida, J. (1982 [1971]). Margins of philosophy. Chicago: Chicago University Press.

Duarte, C. (2005). Portuguesismo, portugalismo, portugalidade, pergunta-resposta. Ciberdúvidas da Língua Portuguesa, 14/2/2005. Retirado de http://tinyurl.com/2ueratv

Ferreira, A. J. (2007). Prefácio. In A. O. Salazar, Como se reergue um Estado (Comment On Relève Un État) (pp.13-20). Lisboa: Esfera do Caos.

Ferronha, A. (1969). Ideário de Portugalidade. Consciência da Luso/Tropicalidade. Porto: Tipografia Marca/Angola: António Ferronha.

Foucault, M. (2010 [1975]). Microfísica do poder. Rio de Janeiro: Graal.

Gomes, M. \& Crisóstomo, P. (2016, 9 de março). Marcelo Rebelo de Sousa foi durante anos o professor que avaliava os outros, nas aulas e nos media. Agora é a vez de ser ele o avaliado. Público. Retirado de http://tinyurl.com/m97pz7n

Henriques, M. C. \& Melo G. S. (2007 [1989]). Salazar. Pensamento e doutrina política. Textos Antológicos. Lisboa: Verbo.

Hall, S. (2000 [1992]). A identidade cultural na pós-modernidade. Rio de Janeiro: DP\&A.

Hobsbawm, E. (1995). A era dos extremos. São Paulo: Companhia das Letras.

Infopédia (2014). Dicionários Porto Editora (Dicionário online de Língua Portuguesa). Retirado de http://tinyurl.com/kspf7gn

Jerónimo, M. B. \& Monteiro, J. P. (2017, 5 de novembro). Por uma vigilância dos usos e abusos da história. P2, Público, pp. 19-21.

Le Goff, J. (1984). Memória. Enciclopédia Einaudi (pp. 11-50). vol. 1 (Memória-História). Lisboa: Imprensa Nacional - Casa da Moeda.

Leiderfarb, L. (2015, 18 de abril). Entrevista a Umberto Eco. Expresso (Revista E), pp. 28-33.

Lorenz, C. (2010). Unstuck in time: the sudden presence of the past. In K. Tilmans, F. Vree \& J. Winter (eds.), Performing the past. Memory, history and identity in modern Europe (pp. 67-105). Amsterdam: Amsterdam University Press. 
Lourenço, E. (1954). Situação do existencialismo. Revista Filosófica, 10: 62-70.

Lourenço, E. (1994 [1988]). Nós e a Europa ou as duas razões. Lisboa: Imprensa Nacional Casa da Moeda.

Lourenço, E. (1998). Nós como futuro. Lisboa: Assírio e Alvim.

Lourenço, E. (1989). Patriotismo e Nacionalismo. Instituto de Defesa Nacional, Nacionalismo e Patriotismo na Sociedade Portuguesa Actual (pp. 1-9). Lisboa: Instituto de Defesa Nacional.

Macedo, J. B.; Maltez, J. A. \& Henriques, C. M. (1999). Bem comum dos portugueses. Lisboa: Vega.

Magalhães, M. (2014). Representação nacional e hiperidentidade. Público, 22/2/2014. Disponível em www.publico.pt/cultura/noticia/representacao-nacional-e-hiperidentidade-1625714. Acesso em 22/2/2014.

Martins, M. L. (1990). O olho de Deus no discurso salazarista. Porto: Edições Afrontamento.

Martins, M. L. (2011). Crise no castelo da cultura. Coimbra: Grácio Editor/CECS-UMinho.

Mattoso, J. (2008). A identidade nacional. Lisboa: Fundação Mário Soares/Gradiva.

Meireles, L. (2016, 20 de agosto). Entrevista a Sanjay Subrahmanyam: O Império português era um Império em rede. Expresso (Revista E), pp. 50-58.

Monteiro, B. \& Domingos, N. (2015). Introdução. Reflexos de um país. In Este país não existe. Textos contra ideias-feitas. (pp. 7-20). Porto: Deriva/Le Monde Diplomatique.

Neves, J. (2016). Os sujeitos da História. In J. Neves. (org.). Quem faz a história? Ensaios sobre o Portugal contemporâneo. (pp. 9-16). Lisboa: Tinta da China.

Pereira, J. M. (2015, 3 de janeiro). Mais português não há. Expresso (suplemento Economia), pp. 16-17.

Pimenta, A. (1947). Em defesa da Portugalidade (Palavras Proferidas na Noite de 11 de Outubro de 1947). Guimarães: Editadas pelos que as ouviram e aplaudiram.

Pimentel, F. E. (1942). A expressão da lusitanidade. Coimbra: Edição "Estudos".

Pinto, A. C. (2015). Os camisas azuis e Salazar. Rolão preto e fascismo em Portugal. Lisboa: Edições 70.

Presidência da República (2016, 10 de janeiro). Homenagem ao Presidente Mário Soares. Mosteiro dos Jerónimos. Retirado de http://tinyurl.com/k4clh6v

Ricoeur, P. (2013 [1987]). Teoria da interpretação. Lisboa: Edições 70.

Ricoeur, P. (2000). La memóire, l'Histoire, l'oubli. Paris: Éditions du Seuil.

Rosas, F. (2012). Salazar e o poder. A arte de saber durar. Lisboa: Edições Tinta da China.

Salazar, A. O. (2007 [1937]). Como se reergue um Estado (Comment On Relève Un État). Lisboa: Esfera do Caos.

Salazar, A. O. (1961). Discursos e notas políticas, vol.2. Coimbra: Almedina. 
Santos, S. S. (2013, 4 de janeiro). Os 40 melhores. Expresso. Retirado de http://tinyurl.com/oq9g7 $7 \mathrm{c}$

Sardica, J. M. (2015). Verdade e erro em história. Lisboa: Universidade Católica Portuguesa.

Sousa, V. (2014). A identidade em tempo de crise. A perda de soberania dos estados, os apelos ao patriotismo e a incerteza do futuro. In M. L. Martins \& M. Oliveira, Comunicação iberoamericana: os desafios da Internacionalização (pp. 1737-1744). Braga: Centro de Estudos de Comunicação e Sociedade/Universidade do Minho. Retirado de

Sousa, V. (2015). Da 'portugalidade' à lusofonia. Tese de Doutoramento em Ciências da Comunicação (Teoria da Cultura). Braga: Universidade do Minho.

Torgal, L. R. (2009). Estados Novos, Estado Novo, vol. 1. Coimbra: Imprensa da Universidade de Coimbra.

Vakil, A. (2006). Heróis do lar, nação ambivalente: portugalidade e identidade nacional nos tempos dos pós-. In M. Loff \& M. C. M. Pereira (coord.), Portugal: 30 Anos de Democracia (1974-2004) (pp.73-101). Porto: Editora da Universidade do Porto.

Wittgenstein, L. (1958). The blue and brown books. Oxford: Blackwell.

Woolf, D. (2006). Of Nations, Nationalism, and National Identity: Reflections on the Historiographic Organization of the Past. In Q. E. Wang \& F. Fillafer (eds.), The many faces of clio cross-cultural approaches to historiography (pp. 71-103). New York: Berghahn Books.

\section{Outras Referências}

http://debates.parlamento.pt 